Jurnal Evaluasi dan Pembelajaran

Volume 3 Nomor 1, Tahun 2021

Available online at https://jepjurnal.stkipalitb.ac.id/index.php/hepi

\title{
PENINGKATAN PRESTASI BELAJAR IPA MELALUI METODE DISCOVERY PADA SISWA KELAS VI SDN 2 HARAPAN JAYA
}

\author{
Maryana \\ SD Negeri 2 Harapan Jaya
}

\begin{abstract}
Abstrak
Penelitian ini bertujuan untuk meningkatkan prestasi dan aktivitas belajar IPA dengan metode penemuan (discovery) pada siswa kelas VI SD Negeri 2 Harapan Jaya Bandar Lampung Tahun 2019. Penelitian ini dilaksanakan di kelas VI SD Negeri 2 Harapan Jaya dengan jumlah 31 orang siswa. Penelitian tindakan ini melalui tiga siklus dan 3 pertemuan tiap siklusnya. Penggunaan metode discovery dalam pembelajaran IPA menunjukkan perkembangan hasil yang meningkat mulai dari siklus I sampai siklus III. Pada siklus I ketuntasan belajar mencapai 53\%. Hal ini disebabkan karena siswa masih merasa baru dan belum mengerti apa yang dimaksud dan digunakan guru dengan menerapkan metode pembelajaran penemuan (discovery). Pada siklus II sudah ada peningkatan $24 \%$ yaitu prestasi belajar menjadi $77 \%$. Pada siklus III meningkat $20 \%$ menjadi $97 \%$. Aktivitas belajar siklus I $53 \%$, Siklus II 73\%, meningkat 20\% dan Siklus III 93\% atau meningkat 20\%. Metode discovery dapat meningkatkan prestasi dan aktivitas belajar IPA siswa kelas VI SD Negeri 2 Harapan Jaya Bandar Lampung Tahun 2019.
\end{abstract}

Kata Kunci: Aktivitas, Discovery, Prestasi

\begin{abstract}
This study aims to improve achievement and science learning activities with discovery methods in class VI Elementary School 2 Harapan Jaya Bandar Lampung in 2019. This research was conducted in class VI Elementary School 2 Harapan Jaya with a total of 31 students. This action research went through three cycles and 3 meetings per cycle. The use of discovery methods in science learning shows an increasing development of results starting from cycle I to cycle III. In the first cycle learning completeness reached $53 \%$. This is because students still feel new and do not understand what the teacher means and uses by applying discovery learning methods. In the second cycle there was an increase of $24 \%$, namely learning achievement to $77 \%$. In the third cycle it increased by $20 \%$ to $97 \%$. Learning activities in cycle I 53\%, Cycle II 73\%, an increase of $20 \%$ and Cycle III $93 \%$ or an increase of $20 \%$. The discovery method can improve the achievement and science learning activities of class VI Elementary School 2 Harapan Jaya Bandar Lampung in 2019.
\end{abstract}

Keywords: Activity, Discovery, Achievement

\section{Pendahuluan}

Guru mengemban tugas yang berat untuk tercapainya tujuan pendidikan nasional yaitu meningkatkan kualitas manusia Indonesia, manusia seutuhnya yang beriman dan bertakwa terhadap Tuhan Yang Maha Esa, berbudi pekerti luhur, berkepribadian, berdisiplin, bekerja keras, tangguh, bertanggung jawab, mandiri, cerdan dan terampil serta sehat jasmani dan 
rohani, juga harus mampu menumbuhkan dan memperdalam rasa cinta terhadap tanah air, mempertebal semangat kebangsaan dan rasa kesetiakawanan sosial. Sejalan dengan itu pendidikan nasional akan mempu mewujudkan manusia-manusia pembangunan dan membangun dirinya sendiri serta bertanggung jawab atas pembangunan bangsa. Depdikbud (1999:37). Berhasilnya tujuan pembelajaran ditentukan oleh banyak faktor diantaranya adalah faktor guru dalam melaksanakan proses belajar mengajar, karena guru secara langsung dapat mempengaruhi, membina, dan meningkatkan kecerdasan serta keterampilan siswa. Untuk mengatasi permasalahan diatas dan guna mencapai tujuan pendidikan secara maksimal, peran guru sangat penting dan diharapkan guru memiliki cara/model mengajar yang baik dan mampu memilih model pembelajaran yang teat dan sesuai dengan konsep-konsep mata pelajaran yang akan disampaikan. Untuk itu diperlukan suatu upaya dalam rangka meningkatkan mutu pendidikan dan pengajaran salah satunya adalah dengan memilih strategi atau cara dalam menyampaikan materi pelajaran agar diperoleh peningkatan prestasi belajar siswa khususnya pelajaran IPA. Misalnya dengan membimbing siswa untuk bersama-sama terlibat aktif dalam proses pembelajaran dan mampu membantu siswa berkembang sesuai dengan taraf intelektualnya akan lebih menguatkan pemahaman siswa terhadap konsepkonsep yang diajarkan. Pemahaman ini memerlukan minat dan motivasi. Tanpa adanya minat menandakan bahwa siswa tidak mempunyai motivasi untuk belajar. Untuk itu, guru harus memberikan suntikan dalam bentuk motivasi sehingga dengan bantuan itu anak didik dapat keluar dari kesulitan belajar.

Kegagalan dalam belajar rata-rata dihadapi oleh sejumlah siswa yang tidak memiliki motivasi belajar.Untuk itu dibutuhkan suatu kegiatan yang dilakukan oleh guru dengan upaya membangkitkan motivasi belajar siswa, misalnya dengan membimbing siswa untuk terlibat langsung dalam kegiatan yang melibatkan siswa serta guru yang berperan sebagai pembimbing untuk menemukan konsep IPA.

Motivasi tidak hanya menjadikan siswa terlibat dalam kegiatan akademik, motivasi juga penting dalam menentukan seberapa jauh siswa akan belajar dari suatu kegiatan pembelajaran atau seberapa jauh menyerap informasi yang disajikan kepada mereka. Siswa yang termotivasi untuk belajar sesuatu akan menggunakan proses kognitif yang lebih tinggi dalam mempelajari materi itu, sehingga siswa itu akan menyerap dan mengendapan materi itu dengan lebih baik. Tugas penting guru adalah merencanakan bagaimana guru mendukung motivasi siswa (Ahmadi \& Uhbiyati, 2001:3). Untuk itu sebagai seorang guru disamping menguasai materi, juga diharapkan dapat menetapkan dan melaksanakan penyajian materi yang sesuai kemampuan dan kesiapan anak, sehingga menghasilkan penguasaan materi yang optimal bagi siswa.

Berdasarkan uraian di atas salah satu metode pembelajaran sebagai alternatif, yaitu metode pembelajaran penemuan (Discovery) untuk mengungkapkan apakah dengan model penemuan (Discovery) dapat meningkatkan motivasi belajar dan prestasi belajar IPA.Penulis memilih metode pembelajaran ini mengkondisikan siswa untuk terbiasa menemukan, mencari, mendiskusikan sesuatu berkaitan dengan pengajaran. (Siadari, 2001:4). Dalam metode pembelajaran penemuan (Discovery) siswa lebih aktif dalam memecahkan untuk menemukan sedang guru berperan sebagai pembimbing atau memberikan petunjuk cara memecahkan masalah ini.

Metode pembelajaran penemuan (Discovery) adalah suatu metode pembelajaran yang memberikan kesempatan dan menurut siswa terlibat secara aktif di dalam mencapai tujuan pembelajaran dengan memberikan informasi singkat (Siadari, 2001:7). Pengetahuan yang diperoleh dengan belajar penemuan (Discovery) akan bertahan lama, mempunyai efek transfer yang lebih baik dan meningkatkan siswa dan kemampuan berfikir secara bebas. Secara umum belajar penemuan (Discovery) ini melatih keterampilan kognitif untuk menemukan dan memecahkan masalah tanpa pertolongan orang lain. Selain itu, belajar penemuan 
membangkitkan keingintahuan siswa, member motivasi untuk bekerja sampai menemukan jawaban (Syafi'udin, 2002:19).

\section{Metode}

Penelitian ini merupakan Penelitian Tindakan Kelas (PTK) yang dilaksanakan dalam tiga siklus dengan masing-masing siklus dilaksanakan dengan empat tahap, yaitu perencanaan, pelaksanaan tindakan, pengamatan, dan refleksi. Penelitian ini dilaksanakan di kelas VI SD Negeri 2 Harapan Jaya dengan jumlah 31 orang siswa. Penelitian ini dilaksanakan melalui 5 tahap, yaitu, (1) tahap perencanaan (2) tahap persiapan, dan (3) tahap pelaksanaan, (4) tahap pengolahan data, dan (5) penyusunan laporan. Indikator kinerja dalam penelitian ini ada dua macam, yaitu: (1) Indikator kinerja yang berkaitan dengan peningkatan prestasi belajar IPA siswa minimal 70\% siswa telah memperoleh nilai minimal 7,0. Dan (2) Indikator kinerja yang berkaitan dengan keberhasilan pelaksanaan pembelajaran yaitu minimal $80 \%$ skenario pembelajaran yang dibuat telah dilaksanakan dengan benar.

\section{Hasil dan Pembahasan}

Penelitian ini dilakukan dengan 3 (tiga) siklus. Prestasi belajar pada siklus I dapat dilihat pada tabel 1 berikut ini:

Tabel 1. Prestasi Belajar Siklus I

\begin{tabular}{|c|c|c|c|}
\hline \multirow[b]{2}{*}{ No } & \multirow{2}{*}{$\begin{array}{l}\text { KODE } \\
\text { SISWA }\end{array}$} & \multicolumn{2}{|c|}{ KETERANGAN } \\
\hline & & TUNTAS & $\begin{array}{c}\text { TIDAK } \\
\text { TUNTAS }\end{array}$ \\
\hline 1 & 001 & TUNTAS & - \\
\hline 2 & 002 & TUNTAS & - \\
\hline 3 & 003 & - & TDK TUNTAS \\
\hline 4 & 004 & TUNTAS & - \\
\hline 5 & 005 & TUNTAS & - \\
\hline 6 & 006 & TUNTAS & - \\
\hline 7 & 007 & - & TDK TUNTAS \\
\hline 8 & 008 & - & TDK TUNTAS \\
\hline 9 & 009 & - & TDK TUNTAS \\
\hline 10 & 010 & TUNTAS & - \\
\hline 11 & 011 & TUNTAS & - \\
\hline 12 & 012 & - & TDK TUNTAS \\
\hline 13 & 013 & - & TDK TUNTAS \\
\hline 14 & 014 & - & TDK TUNTAS \\
\hline 15 & 015 & - & TDK TUNTAS \\
\hline 16 & 016 & TUNTAS & - \\
\hline 17 & 017 & - & TDK TUNTAS \\
\hline 18 & 018 & TUNTAS & - \\
\hline 19 & 019 & TUNTAS & $=$ \\
\hline 20 & 020 & - & TDK TUNTAS \\
\hline 21 & 021 & TUNTAS & - \\
\hline 22 & 022 & TUNTAS & - \\
\hline 23 & 023 & - & TDK TUNTAS \\
\hline 24 & 024 & TUNTAS & - \\
\hline 25 & 025 & - & TDK TUNTAS \\
\hline 26 & 026 & TUNTAS & - \\
\hline 27 & 027 & - & TDK TUNTAS \\
\hline
\end{tabular}


Jurnal Evaluasi dan Pembelajaran, 3 (1), Maret 2021 - 10

Maryana

\begin{tabular}{lccc}
\hline \multirow{2}{*}{ No } & \multirow{2}{*}{ KODE } & \multicolumn{2}{c}{ KETERANGAN } \\
\cline { 3 - 4 } & SISWA & TUNTAS & $\begin{array}{c}\text { TIDAK } \\
\text { TUNTAS }\end{array}$ \\
\hline 28 & 028 & - & TDK TUNTAS \\
\hline 29 & 029 & TUNTAS & - \\
\hline 30 & 030 & TUNTAS & - \\
\hline Jumlah & 16 & 14 \\
\hline $\begin{array}{l}\text { \%ketuntasan per } \\
\text { item/klasikal }\end{array}$ & $53 \%$ & $47 \%$ \\
\hline
\end{tabular}

Dari tabel 1 dapat dijelaskan bahwa dengan menerapkan metode pembelajaran penemuan (discovery) diperoleh nilai rata-rata prestasi belajar siswa adalah 62 dan ketuntasan belajar mencapai $53 \%$ atau ada 16 siswa dari 30 siswa sudah tuntas belajar. Data tersebut menunjukan bahwa pada siklus pertama secara klasikal siswa belum tuntas belajar, karena siswa yang memperoleh nilai $\geq 70$ hanya sebesar $53 \%$ lebih kecil dari persentase ketuntasan yang dikehendaki yaitu sebesar 85\%. Aktivitas belajar Siklus I adalah 53\%, hal ini disebabkan karena siswa masih merasa baru dan belum mengerti apa yang dimaksudkan dengan digunakan guru dengan menerapkan metode pembelajaran penemuan (discovery).

Selanjutnya, prestasi belajar pada siklus II dapat dilihat pada tabel 2 berikut ini:

Tabel 2. Hasil Penelitian Siklus II

\begin{tabular}{|c|c|c|c|}
\hline \multirow{2}{*}{ No } & \multirow{2}{*}{$\begin{array}{l}\text { KODE } \\
\text { SISWA }\end{array}$} & \multicolumn{2}{|c|}{ KETERANGAN } \\
\hline & & TUNTAS & TDK TUNTAS \\
\hline 1 & 001 & TUNTAS & - \\
\hline 2 & 002 & TUNTAS & - \\
\hline 3 & 003 & - & TDK TUNTAS \\
\hline 4 & 004 & TUNTAS & - \\
\hline 5 & 005 & TUNTAS & - \\
\hline 6 & 006 & TUNTAS & - \\
\hline 7 & 007 & TUNTAS & \\
\hline 8 & 008 & TUNTAS & \\
\hline 9 & 009 & - & TDK TUNTAS \\
\hline 10 & 010 & TUNTAS & - \\
\hline 11 & 011 & TUNTAS & - \\
\hline 12 & 012 & TUNTAS & \\
\hline 13 & 013 & TUNTAS & \\
\hline 14 & 014 & TUNTAS & \\
\hline 15 & 015 & - & TDK TUNTAS \\
\hline 16 & 016 & TUNTAS & - \\
\hline 17 & 017 & - & TDK TUNTAS \\
\hline 18 & 018 & TUNTAS & - \\
\hline 19 & 019 & TUNTAS & $=$ \\
\hline 20 & 020 & - & TDK TUNTAS \\
\hline 21 & 021 & TUNTAS & - \\
\hline 22 & 022 & TUNTAS & - \\
\hline 23 & 023 & TUNTAS & \\
\hline 24 & 024 & TUNTAS & - \\
\hline 25 & 025 & - & TDK TUNTAS \\
\hline 26 & 026 & TUNTAS & - \\
\hline 27 & 027 & - & TDK TUNTAS \\
\hline 28 & 028 & TUNTAS & \\
\hline 29 & 029 & TUNTAS & - \\
\hline 30 & 030 & TUNTAS & - \\
\hline SKO & SISWA & 23 & 7 \\
\hline $\begin{array}{l}\% \mathrm{ke} \\
\text { item }\end{array}$ & $\begin{array}{l}\text { untasan per } \\
\text { klasikal }\end{array}$ & $77 \%$ & $23 \%$ \\
\hline
\end{tabular}


Dari tabel 2 diperoleh nilai rata-rata prestasi belajar siswa adalah 84 dan ketuntasan belajar mencapai $77 \%$ atau ada 23 siswa dari 30 siswa sudah tuntas belajar. Data menunjukan bahwa pada siklus II ini ketuntasan belajar secara klasikal telah mengalami peningkatan sedikit lebih baik dari siklus I. Aktivitas belajar adalah $73 \%$ meningkat $20 \%$, Adanya peningkatan prestasi dan aktivitas belajar siswa ini karena setelah guru menginformasikan bahwa setiap akhir pelajaran akan selalu diadakan tes sehingga pada pertemuan berikutnya siswa lebih termotivasi untuk belajar. Selain itu juga siswa sudah mulai mengerti apa yang dimaksudkan dan diinginkan guru dengan menerapkan metode pembelajaran penemuan (discovery).

Selanjutnya, hasil penelitian pada siklus III sebagai berikut:

Tabel 3. Hasil Penelitian Siklus III

\begin{tabular}{|l|l|l|c|}
\hline \multirow{2}{*}{ No } & \multirow{2}{*}{$\begin{array}{c}\text { KODE } \\
\text { SISWA }\end{array}$} & \multicolumn{2}{|c|}{ KETERANGAN } \\
\cline { 3 - 4 } & TUNTAS & TDK TUNTAS \\
\hline 1 & 001 & TUNTAS & - \\
\hline 2 & 002 & TUNTAS & - \\
\hline 3 & 003 & TUNTAS & - \\
\hline 5 & 004 & TUNTAS & - \\
\hline 6 & 005 & TUNTAS & - \\
\hline 7 & 007 & TUNTAS & - \\
\hline 8 & 008 & TUNTAS & - \\
\hline 9 & 009 & TUNTAS & - \\
\hline 10 & 010 & TUNTAS & - \\
\hline 11 & 011 & TUNTAS & - \\
\hline 12 & 012 & TUNTAS & - \\
\hline 13 & 013 & TUNTAS & - \\
\hline 14 & 014 & TUNTAS & - \\
\hline 15 & 015 & - & TDK TUNTAS \\
\hline 16 & 016 & TUNTAS & - \\
\hline 17 & 017 & TUNTAS & - \\
\hline 18 & 018 & TUNTAS & - \\
\hline 19 & 019 & TUNTAS & - \\
\hline 20 & 020 & TUNTAS & - \\
\hline 21 & 021 & TUNTAS & - \\
\hline 22 & 022 & TUNTAS & - \\
\hline 23 & 023 & TUNTAS & - \\
\hline 24 & 024 & TUNTAS & - \\
\hline 25 & 025 & TUNTAS & - \\
\hline 26 & 026 & TUNTAS & - \\
\hline 27 & 027 & TUNTAS & - \\
\hline 28 & 028 & TUNTAS & - \\
\hline 29 & 029 & TUNTAS & - \\
\hline 30 & 030 & TUNTAS & - \\
\hline SKOR SISWA & 29 & \\
\hline$\%$ & ketuntasan & $97 \%$ & \\
klasikal & & - \\
\hline & & & \\
\hline & & & - \\
\hline
\end{tabular}

Berdasarkan tabel 3 di atas diperoleh nilai rata-rata tes formatif sebesar 89 dan dari 30 siswa yang tuntas sebanyak 29 siswa dan 1 siswa belum mencapai ketuntasan belajar. Maka secara klasikal ketuntasan belajar yang telah tercapai sebesar $97 \%$ (termasuk kategori tuntas). Hasil pada siklus III ini mengalami peningkatan lebih baik dari siklus II. Aktivitas belajar adalah $93 \%$ atau meningkat $20 \%$. Adanya peningkatan prestasi dan aktivitas belajar siswa ini dipengaruhi oleh adanya peningkatan kemampuan guru dalam menerapkan pembelajaran 
penemuan (discovery) sehingga siswa menjadi lebih terbiasa dengan pembelajaran seperti ini sehingga siswa lebih mudah dalam memahami materi yang telah diberikan. Pada siklus III ini ketuntasan secara klasikal telah tercapai, sehingga penelitian ini hanya sampai pada siklus III.

Metode discovery berdasarkan hasil penelitian mampu meningkatkan aktivitas dan prestasi belajar siswa. Discovery merupakan belajar menemukan sendiri. Dalam sistem belajar mengajar ini guru menyajikan bahan pelajaran tidak dalam bentuk final, tetapi anak didik diberi peluang untuk mencari dan menemukan sendiri. (Roestiyah, 2012:20). Sanjaya (Rohayati, 2017), dalam discovery ini bahwa bahan pembelajaran dicari dan ditemukan sendiri oleh peserta didik melalui berbagai aktivitas, sehingga tugas guru lebih banyak sebagai fasilitator dan pembimbing bagi peserta didik. Dengan konsep tersebut peserta didik diberi kesempatan untuk mengeksplorasi segala kemampuannya dalam proses belajar dan akan dapat meningkatkan minat dan motivasinya. Peserta merasa senang mendapatkan pembelajaran yang lebih bermakna karena membantu peserta didik dalam menyelesaikan masalah dengan menghubungkan pengetahuanpengetahuan yang telah ada dengan konsep yang sedang dipelajari.

\section{Simpulan}

Simpulan dapat bersifat generalisasi temuan sesuai permasalahan penelitian, dapat pula berupa rekomendatif untuk langkah selanjutnya. Berdasarkan hasil penelitian dan pembahasan yang telah dilakukan dapat disimpulkan sebagai berikut:

1. Metode Pembelajaran penemuan (discovery) dapat meningkatkan prestasi belajar IPA siswa kelas VI SD Negeri 2 Harapan Jaya Bandar Lampung Tahun 2019, yang ditandai dengan peningkatan ketuntasan belajar siswa dalam setiap siklus, yaitu siklus I adalah $(53 \%)$, siklus II adalah (77\%), meningkat $24 \%$, dan siklus III adalah (97\%), meningkat $20 \%$.

2. Metode pembelajaran penemuan (discovery), dapat meningkatkan aktivitas belajar IPA siswa SD Negeri 2 Harapan Jaya Bandar Lampung Tahun 2019. Ditandai dengan meningkatnya aktivitas belajar siswa dari Siklus I adalah (53\%), siklus II adalah (73\%), atau meningkat $20 \%$, Siklus III adalah (93\%) atau meningkat $20 \%$.

\section{Daftar Pustaka}

Depdikbud, 2001. Kamus Besar Bahasa Indonesia. Jakarta : Balai Pustaka.

Ahmadi, H.Abu \& Uhbiyati, Nur. 2001. Ilmu Pendidikan. Jakarta: Rineka Cipta.

Siadari. 2001. Model Pembelajaran Penemuan Konsep. Bandung: Remadja Karya.

Roestiyah. 2012. Strategi Belajar Mengajar. Jakarta : PT.Rineka Cipta.

Rohayati. 2017. Peningkatan Hasil Belajar IPA Melalui Strategi Discovery Learning di Kelas V Sekolah Dasar.

Syafi'udin. 2002. Penerapan Pendekatan Konstruktivis dengan menggunakan Metode Penemuan untuk Meningkatkan Prestasi Belajar Siswa Kelas I MTsN Denanyar. Skripsi. Universitas Negeri Surabaya. 